\title{
ANALYSIS OF LAND PARKING INVESTMENT CASE STUDY IN ROAD R. SUPRAPTO PURWODADI CITY GROBOGAN DISTRICT
}

\author{
Heri Sulistiyono ${ }^{1}$ \\ Nina Anindyawati ${ }^{2}$
}

Master of Civil Engineering, Sultan Agung Islamic University ${ }^{1,2}$

Corresponding Author Email: anindyawati@ unissula.ac.id

\begin{abstract}
Population growth and growth of economic sector, causing high level of population mobility or high level of travel. Increased vehicle travel that is not followed by an increase in the quality and quantity of adequate transport infrastructure can lead to an imbalance between greater travel demands compared to the availability of existing transport infrastructure. Based on the above background, the existence of economic growth in Purwodadi City thus increasing the purchasing power and mobility of the population so that the density on the Road. R. Suprapto which is the main road or vein of Purwodadi City so that parking problem in Jalan R. Suprapto need to get serious attention.

This study aims to determine the calculation of profit and loss for parking investment land. In detail the purpose of the study can be mentioned as follows: To know the parking area needed to fulfill the need. To know the pattern of parking arrangement that fit the optimal needs. To improve management of parking management in the study location. To find out the feasibility of investment of parking facility in the location of study.

Data analysis performed include analysis of parking facility characteristics, parking forecasting analysis analysis and financial feasibility analysis of parking building development. as for the analysis technique using: Characteristic Analysis of Parking Facility and Financial Feasibility Analysis of Parking Building Development.

Based on the evaluation of the financial feasibility parameters of the parking lot development project can be obtained the following results: Based on the feasibility analysis of the project, the construction of the parker is financially feasible to run. The construction of a parking space on Jalan R Suprapto Kota Purwodadi has economic and social benefits for the people of Grobogan Regency, especially in the region. Break Even Point (BEP) Construction of parking spaces on Jalan $R$ Suprapto Kota Purwodadi is 3.49 or BEP occurs in the $3 r d$ and 3rd months of the 3rd day.
\end{abstract}

Keywords : Parking Feasibility Analysis, NPV, IRR, BCR, Road Section R Suprapto

\section{INTRODUCTION}

Gross Regional Domestic Product (GDP) per capita is one of the indicators macro economy to see the economic development and welfare level of society in a region. By looking at the PDRB per capita of a region, it will show the level of welfare of the community. GRDP per capita of Grobogan Regency for the last five years has increased, both based on Current Prices and Constant Price. Based on GDP per capita growth data Year 2013 based on Constant Price of Rp.2.601.710,00 or up 3.75\% from the previous year. Meanwhile, based on the current price of Rp.6.210.840,00 or an increase of 10.15\% (Grobogan District 
BPS 2014). This shows that the economic growth of the people in Grobogan district has increased so that the purchasing power of the community also increases.

In line with the economic improvement of the people in Grobogan Regency indirectly caused the movement of traffic is quite dense, causing congestion seen in several major roads and intersections in Purwodadi City such as Road R. Suprapto. The heavy traffic movement caused various problems such as on street parking, delay, side barriers and so forth. Roadside parking is an interesting phenomenon to learn because on the one hand it is the most common choice of drivers and on the other side a side barrier that can affect road performance.

Jalan R. Suprapto is one of the protocol streets in Purwodadi City which is also an economic center, because in the street there are many trading centers so that many community activities occur in the road. However, the provision of parking lots by both government and entrepreneurs is still not in accordance with the needs, it affects the occurrence of parking along the street (on street Parking).

In an effort to deal with parking problems on the street R. Suprapto Grobogan District Government through the Department of Communication and Information seek to reform the system of parking along the road R. Suprapto, using the road as a parking location, with parallel pattern on the right and left of the road yet until now has not been able to provide space for parking needs .

Research on the Analysis of the Feasibility of Parking Land Investment (Case Study On Road R. Suprapto Purwodadi City Grobogan Regency) is aimed as follows:

1. To know the parking area needed to fulfill the need

2. To know the pattern of parking arrangement that fit the optimal needs

3. To improve management of parking management in the study location

4. To know the feasibility of investment of parking facility in the location of study This research is expected to be useful for various parties. These benefits include :

1. It is expected to be an input and consideration in solving vehicle parking problems, and reducing vehicle buildup.

2. Can be a material input and consideration in solving the problem of vehicle parker management, reduce traffic congestion and parking chaos.

3. Can add insight in analyzing parking issues. 


\section{LITERATURE REVIEW}

\section{Parking Operations}

Parking is a state of immobile a vehicle that is temporary (Abubakar, 1998). The definition of parking is any vehicle that stops at a certain place that is declared with a sign or not, and not solely to raise and or lower the goods and or people.

The most important part of the modern community transportation system is one of them is the development of parking. If parking planning fails the impact is the occurrence of congestion in an activity and difficulty in finding a parking lot. In general, parking consists of 2 types of parking is parking on the street (on-street parking) and off -street parking (off-street parking).

\section{Parking Characteristics}

Information on the characteristics of parking is necessary when planning a parking lot. Some parking characteristic parameters that must be known are:
a. Parking Duration
b. Parking Accumulation
c. Parking capacity
d. Provision of parking (Parking supply)
e. Parking index
f. Parking lot needs

\section{Investment Appraisal Criteria}

In the financial analysis there are several criteria used in determining the acceptance or absence of an investment proposal. In all of these criteria, whether the benefits (benefits), and cost (cost) is expressed in present value (Net Present vlue), and brackish $g$ - each has advantages and disadvantages criteria (Giatman, 2006). There are several methods to evaluate commonly used investment feasibilities: Net Present Value (NPV) Method , Annual Equivalent (AE) Method, Internal Rate of Return (IRR) Method, Benefit Cost Ratio (BCR) Method and Payback Period Method ).

Payback Period method basically aims to find out how long the investment will be restored sa a t the occurrence of basic conditions home (break event point). The Annual Equivalent method concept is the reverse of the NPV (all cash flows are withdrawn in present form ), in which the cash flow will be distributed evenly over the lifetime of the investment. Equitable distribution results earn annual revenue or Annual Equivalent ( $\mathrm{AE}$ ). The following is an explanation of NPV, BCR and IRR : 


\section{a. Net Present Value (NPV)}

Calculates the difference between the present value of an investment and the present value of future net cash receipts.

To calculate the present value it is necessary to specify the relevant interest rate first . If the present value of future cash receipts is greater than the present value of the investment, then this is said to be profitable / acceptable, but if it is smaller then the investment is rejected. The NPV value can be calculated by the following formula (Giatman, 2006):

Where :

$\mathrm{CFt}=$ Cash flow intact (benefit $+\cos \mathrm{t})$

FBP $=$ Current interest factor.

NPV $>0$, then the investment is profitable

NPV $<0$, then the investment is not profitable

\section{b. Benefit Cost Ratio}

A comparison between the net benefits of the current year that have been assessed, In this criterion differentiated the years where there is a positive net benefit and years where net benefits are negative. So benefit Cost Ratio is Net Benefit Positive divided Net Benefit Negative obtained and calculated by the following formula (Giatman, 2006)

$\mathrm{n}$

$\sum \mathrm{Cbt}(\mathrm{FBP})$

$$
\mathrm{t}=0
$$

BC Ratio $=2.9$

n

$\sum \operatorname{Cct}(\mathrm{FBP})$

$$
\mathrm{t}=0
$$

Where :

$\mathrm{Cbt}=$ Cash flow benefit / year profit '

Cct $=$ Cash flow cost $/$ year in year ' $t$ '

$\mathrm{I}=$ discount rate $/$ interest rate $(\%$ per year $)$

$\mathrm{n}=$ age of plan

$\mathrm{FBP}=$ present interest factor

$\mathrm{BCR} \geq 1$, then the investment feasible (feasible) 
BCR $<1$, then unfeasible investment (unfeasible)

\section{c. Internal Rate of Return}

It is the interest rate (discount rate) that can make the NPV price of a project value of 0 , or BC Ratio equal to 1 (one). In the IRR account, it is assumed that each year net benefits are automatically replanted within the next year, and earn the same Rate of Return as the previous investment. Large IRR is searched with Trial and Error method , first set the required unit " $i$ " approaching IRR. If the value of the calculation gives a negative NPV value is greater than the IRR, if this is achieved, then interpolated between the highest discount rate (still gives a positive value) and a low discount rate that gives a negative NPV value so that the value obtained for 0 .

These IRR criteria provide guidance that the business to be selected is acceptable if it is greater than the prevailing interest rate (IRR $\geq i$ ) and if IRR is less than the interest rate, then the business is not feasible.

\section{d. Sensitivity Analysis}

This analysis is useful to know the extent to which the impact of investment parameters that have been set may change due to the factors of the situation and conditions over the life of the investment, so that the changes will have a significant effect on the decisions taken. In reality there are changes and price fluctuations that can be ignored and will not alter the previous evaluation decision. The limit of the value of the change which will be able to reverse the previous decision is called with the sensitivity level of the parameter under test.

e. Sensitivity analysis can be reviewed on two perspectives:

i. Sensitivity to itself, the sensitivity of the BEP (Break Even Point) condition at the time of NPV $=0$. Analyzing the sensitivity can be done on initial cost, sensitivity to benefit, sensitivity to operational or sensitivity to interest rates (Giatman, 2006). Where :

$\mathrm{CF}=$ Investment Cash Flow FBP $=$ Present Flower Factor

ii. Sensitivity to other alternatives, usually found when there are $\mathrm{N}$ alternatives to choose ( $\mathrm{N}$ alternatives one should choose to implement) with different parameters of different analyzes. 


\section{METHODOLOGY}

1. Troubleshooting Analysis Framework

Research Procedure Characteristic of Parking Needs can be explained as follows:

a. Preliminary studies

Carry out observations and initial checks on the location to be made as the object of study

b. Problem Determination and Destination Setting

From the results of observations and early checks can be in the know problems at the study site, and can be determined the purpose of the study to be carried out

c. Scope of problem

Provide limitations of issues to be discussed, so that the study is more specific and directed to the completion of a problem.

d. Data collection

Carry out data collection from various sources, as well as field data. The data is differentiated into 2 (two ) ie primary data and secondary data.

e. Data processing

Results of field data and data from various sources collected for further technical calculations, including design planning and data analysis.

f. Cash Flow / Cash Flow

To know the existence of cash on the balance sheet.

g. Financial Feasibility Analysis

To determine the feasibility of investing financially. This analysis includes 3 kinds :

i. Benefit Cost Ratio

ii. Net Present Value

iii. Internal Rate of Return

h. Payback Period / Range Back Method Aims to determine the period of return of investment value.

i. Sensitivity / Size Accuracy

To know the extent to which the calculation results in accordance with the reality in the field. 


\section{j. Conclusion}

To clarify whether the hypothesis suggested can be accepted or rejected, the conclusion in scientific research is the essence of the experiments and statements about the relationship of the experimental results with the hypothesis.

\section{Data Acquisition}

Data acquisition is carried out in a designated location to obtain a clear picture of the parking characteristics. There are 2 (two) surveys conducted to obtain data: The Direct Surveillance Survey on the Ground is the Cordon Counts and Parking Inventory Survey.

a. Kordon survey (Cordon count)

Survey of direct observation in the field using cordon count survey . In this method the study area is limited to the cordon area. Station calculation at the exit / entrance. The sum of vehicles entering and leaving the area will give an idea of the accumulation of vehicles in the study area. The number of vehicles at a time can describe the vehicle parking and the total number of vehicle movements. By reducing the number of moving vehicles then the required amount of parking space can be obtained. The number obtained is the control function of all the planning and traffic arrangement. Conducting the survey is done by manual or automatic way, the selection takes into account the resources and funds. In detail the data can be obtained are:

i. Number of parking vehicles.

ii. Rate of arrival and departure.

iii. Parking Duration and Parking Accumulation.

iv. Population composition.

One of the easiest ways to apply for building parking or parking lot is to record the number of vehicles through the entrance of vehicles entering and exiting from each type of vehicle. Based on the combination of these two data will be obtained duration of parking time and parking accumulation .

b. Parking Inventory Survey

The expected form of parking inventory is to collect the complete parking data possible in the study area. In order to recognize the situation, the plan is required and the scheme is poured as much information as possible, noting the various facilities that exist at the moment, including the possibility of development. Locations that may 
be used as parking lots will be included in the discussion. Important information related to this provision include:

i. Park space ir - number of vehicles and geographical conditions.

ii. Type of parking - curb, inside buildings, levels and others.

iii. Operation procedure.

iv. Parking fee - fixed, variable, permit, parking subscription and so forth.

v. A macro map is required as part of the current information. This map will be created as a base of analysis so that traffic and parking conditions can be displayed. This information is illustrated by the placement of signs and markers. This map need not detail but enough to inform where the location of parking, entrance, exit, the surrounding buildings and circulation of traffic flow within the location / area to be studied.

\section{c. Data analysis}

Data analysis performed include analysis of parking facility characteristics, parking forecasting analysis analysis and financial feasibility analysis of parking building development with the following explanation:

i. Characteristic Analysis of Parking Facility

ii. The initial analysis used is matching the number of vehicle plate, after which sought accumulation and parking duration. Characteristics distinguished by the type of vehicle (car and motor) The number of available parking stalls adjusted for the amount available for the motor and car Analysis of duration, accumulation, parking volume using microsoft excel,

iii. Financial Feasibility Analysis of Parking Building Development.

The investment cost / Initial Cost is calculated based on the current Budget Plan. While the interest rate used is the current interest rate or from BPS data of Central Java Province . Revenues are the result of parking rates (progressive rates) for 4wheeled vehicles and fixed tariffs for 2-wheeled vehicles adjusted to the prevailing tariff standards multiplied by the number of time union vehicles. Once obtained these costs value is made in the form of Present and poured in the form of cash flow diagram, then calculated NPV and BC ratio. The final step is to analyze the feasibility and sensitivity to take a conclusion and suggestion. Sensitivity to itself, the sensitivity of the BEP (Break Even Point) condition that is at the time of NPV $=0$. Analyzing the 
sensitivity can be done on initial cost, sensitivity to benefit, sensitivity to operational or sensitivity to interest rates.

\section{DISCUSSION AND ANALYSIS}

According to Husnan and Suwarsono (2000) there are five methods that can be considered to be used in the assessment of investment, including:

1. Net Present Value (NPV)

This criterion says that the project will be selected if NPV $>0$. This project has NPV positive as big 426.028.610.52 so it belongs to category NPV >0 so project feasible to be done financially.

\section{Profitability Index or BC Ratio}

Profitability Index or Benefit and Cost Ratio (BC Ratio) is a method of calculating the comparison between the present value of future net cash receipts and the present value of investments. If the Profitability Index (IP) is bigger than one, then the project is said to be profitable, but less than one then it is not profitable. As with the NPV method, this method needs to first determine the interest rate to be used (Husnan and Suwarsono 2000: 211). In cashmere and jakfar (2003), the formula used to find the PI or BC ratio is as follows:

PI:

3. Internal Rate of Return (IRR)

According to Husnan and Suwarsono (2000: 210), the method of Internal Rate of Return (IRR) is to calculate the interest rate that equates the present value of the investment with the present value of net cash receipts in the future. If the interest rate is greater than the relevant interest rate (the required rate of return), then the investment is said to be profitable, if it is less harmful.

According to Rianto (1995), that IRR can be calculated using the following formula :

Where :

$\mathrm{IRR}=$ internal reat of return searched

$\mathrm{P} 1=1$ st interest rate

$\mathrm{P} 2=$ the second interest rate

$\mathrm{C} 1=1$ st NPV

$\mathrm{C} 2=2$ nd NPV

In Husnan and Suwarsono , (1999). The formula of IRR is as follows: 
$\operatorname{IRR}=$

Information :

$I^{\prime}$ ' = interest rate on first interpolation (smaller)

I " = interest rate on second interpolation (greater)

NPV ' = NPV value at first discount rate (positive)

NPV " = NPV value at second discount rate (negative)

\section{Payback Period (PP)}

According to Husnan and Suwarsono ( 2000: 208), suggests that Payback Period is a method that tries to measure how quickly investment can return. Therefore the unit of result is not the percentage, but the unit of time (month, year and so on). If the payback period is shorter than required, then the project is said to be profitable, whereas if it is longer the project is rejected.

This method measures how quickly an investment can return, then the basis used is cash flow, not profit: for that we first calculate the cash flow from the project. The main problem of this method is the difficulty of determining the maximum indicated payback period, to be used as a comparison number. Normatively, there are no guidelines that can be used to determine this maximum payback. In practice the payback is generally used from similar companies.

Based on the average calculation of BEP Value for all segments $=3$, 49 it can be concluded that $\mathrm{PP}=3.49$ years shorter than the economical time of the project ( 5 years) then the project belongs to the category of project that is feasible to work financially.

\section{Break Even Point (BEP)}

Break Even Point (BEP) is a condition where all revenue is only able to cover all expenses or in other words that break even point will happen where total benefit = total cost. From the calculation table that the BEP for all segments (1-16) occurs between the 3rd and 4th years so that by means of linear regression sought for NPV $=0$ it is found that the average break even point for all segments is 3.49 or can be interpreted to occur in the 3 rd year of the 3rd day of the 9th day does not exceed the economic time of the 5 year established project.

\section{CONCLUSIONS}

Based on the evaluation of the financial feasibility parameters of the parking lot development project can be obtained the following results : 
1. To move the parking on the road (On street Parking) to the parking outside the road (Of street Parking) On the road of R. Suprapto city of Purwodadi along the $1585 \mathrm{~m}$, the required area of $2984 \mathrm{~m} 2$ can be divided into several parking pockets with parking center at the point between segment 6 to segment 10 or at Sta $0+600$ to Sta $1+000$.

2. To optimize the parking lot, in order to accommodate the number of vehicles with large volumes then the ideal parking arrangement pattern is to pattern the island by forming an angle of $90^{\circ}$.

3. From the research results need to make changes to the management of existing parking management, so the results of parking revenue, especially for contributions to the local government can be maximized.

4. Based on the evaluation of the financial feasibility parameters of the parking lot development project can be obtained the following results :

Based on the feasibility analysis of the project, the construction of the parking lot is financially feasible to run .

The construction of a parking lot in Jalan R Suprapto Kota Purwodadi has benefits economy and social for community Grobogan district is mainly on regional income .

Break Even Point (BEP) The construction of parking lot in Jalan R Suprapto Kota Purwodadi is 3, 49 or BEP happened on year to 3 months to 3 days to 9 .

The suggestions that can be given are:

1. For anticipating economic conditions and changing government policies at all times where changes in policy will affect the value of the project is required technical economic analysis with consideration of parameters and the addition of other data analysis methods to produce a more sharp and accurate analysis.

2. Although reviewed from analysis economy technique feasible however could considered social conditions that arise with the existence of the place parker.

\section{REFERENCES}

Abubakar, Iskandar et al. 1998. City Transportation System. Jakarta: Directorate of Urban Traffic and Transportation System.

Adler, Ronald B., and Rodman, George, 1982. Human Comunication . New York: Rinehart and Winston, Inc.

Alfan NR, 2014, Parking Planning Study In Malang Region Olympic Garden, Universitas Brawijaya, Malang. 
Black, 1981, Transport Planning and Modeling : Theory and Practice, Cromm Helm, London. DeGarmo, EP, WG Sullivan, JR Canada. (1984), Engineering Economy, Seventh Edition, Macmillan Publishing Company.

Directorate General of Land Transportation, Directorate of City Traffic and Transportation System, Ministry of Transportation. (1998), Guidelines for Planning and Operation of Parking Facility, Jakarta.

Giatman, M., 2006, Engineering Economics, Raja Grafindo Persada, Jakarta.

Harimurti, Bayu W., Wijaya K and Heru N. 2018. Parking Management System With NFC . Journal of Information Technology Development and Computer Science. Vol. 2 No. 6. P. 2038-2045.

Hobbs, FD 1979, Interpretation: Ir. Suprapto M., MSC., Ir. Waldijono. Traffic Planning and Techniques, 2nd Edition. Gadjah Mada University Press, Yogyakarta.

Kartika, AAG (2008), the concept of Value of Money (Discounted Value), Materials S2 Lecture : Transportation Economics. Sepuluh Nopember Institute of Technology, Surabaya.

Khisty, Jotin and B. Kent Lall. 2003. Fundamentals of Transportation Engineering Volume 1. Erlangga. Jakarta.

Kodoatie, Robert J. 1995. Technical Economic Analysis, Yogyakarta: Andi

Munawar, A. (2004), Urban Traffic Management, Beta Offset, Jogjakarta.

Mulyadi, 2005, Cost Accounting, STIE YKPN, Yogyakarta.

PC, Box. and C. Oppenlander, Josepsh. 1976. Manual of Trafic Engineering Studies, 4th edition. Washington, DC: Institute of Transportation Engineers.

Saridewi, 2009, Parking Demand Analysis at Various Lands in Legian Kuta Bali, National Seminar on Regional Needs, ITS Surabaya

Soeharto, Faith. 1995. Project Management: From Conceptual to Operational. Jakarta: Erland.

Suluh KM, 2013, Effectiveness of Main Traditional Market Parking in Surakarta City, digilib, UNS, Surakarta.

Tamin, OZ (2000), Transport Planning and Modeling, Second Edition, Bandung Institute of Technology, Bandung.

Tamin, OZ (2003), Transport Planning and Modeling: Sample Problem and Application, First Edition, Bandung Institute of Technology, Bandung.

Tamin, OZ, 2008, Planning, Modeling and Transport Engineering, ITB, Bandung. 